\title{
Reading Horace in 1490s Padua: Willibald Pirckheimer, Joannes Calphurnius and Raphael Regius
}

\author{
Paul White ${ }^{1}$
}

Published online: 11 January 2016

(C) The Author(s) 2016. This article is published with open access at Springerlink.com

Horace's Epistle I.2, a poem about the benefits to be derived from reading Homer, was a key text for the grammarians and commentators of the Middle Ages and Renaissance, since it provided an ethical justification for the centrality of poetry to education. ${ }^{1}$ If medieval commentators were anxious about the use of pagan poetry in Christian education, they had only to emphasize the moral instruction it furnished by means of example and negative example. Discussions of intention and utility in the prologues habitually presented poetic texts as reprehending vice and commending virtuous conduct. In the Renaissance, such exemplary readings of poetic texts persisted, frequently identified with the aims and methods of epideictic, the rhetoric of praise and blame. $^{2}$ Such readings were central to the way study of poetic texts was framed and justified in theory; practice was, perhaps, a different matter. Despite the claims made in prefaces and accessus that the study of poetry provided a solid moral education for the

\footnotetext{
${ }^{1}$ Generally on this poem see: Catherine Keane, 'Lessons in Reading: Horace on Homer at Epistles 1.2.131', Classical World, 104.4, 2011, pp. 427-50.

2 Suzanne Reynolds, Medieval Reading: Grammar, Rhetoric, and the Classical Text, Cambridge, 1996, pp. 14-15. See also my discussion of Badius Ascensius's 1503 commentary on Epistles I.2, Jodocus Badius Ascensius: Commentary, Commerce and Print in the Renaissance, Oxford, 2013, pp. 256-7.
}

\begin{abstract}
Note on transcriptions: I have done my best to transcribe all Greek words exactly as they appear in Pirckheimer's handwritten notes, which mostly omit accents and breathings. Pirckheimer makes some errors in the Greek which I do not attempt to correct, marking only particularly striking or unusual spellings with sic. I have adopted $\varsigma$ for final sigma throughout. In the Latin the standard abbreviations are resolved and marked with square brackets; in places where I add my own conjectures for portions of the text that are missing because of trimmed margins, or otherwise illegible, I place these between square brackets.
\end{abstract}

Paul White

p.m.white@leeds.ac.uk

1 School of Languages, Cultures and Societies, University of Leeds, Leeds LS2 9JT, UK 
young, in practice the commentators mainly busied themselves accumulating discrete items of information about language, history and myth, and offered little by way of cohesive moral instruction. The question of how moral learning gleaned from poetic texts should be applied in practice was largely ignored in the commentaries, perhaps considered a matter for the oral exchanges of the schoolroom and lecture theatre.

Historians of medieval and Renaissance education, surprised by the relative paucity of morally instruction in the commentaries, have disagreed about the mechanisms for its delivery, and have doubted their effectiveness. ${ }^{3}$ The best evidence for the application of ideas found in the commentaries and textbooks is surely to be found in notes taken down by students in the midst of real teaching situations. Let us consider, for example, a short passage from Horace's poem on what poetry can teach us:

...qui non moderabitur irae:

infectum volet esse: dolor quod suaserit et mens:

dum poenas odio per vim festinat inulto (Epistles I.2.59-61)

The man who will not check his anger will wish undone what his indignant mood prompted, when he was quick to seek retribution by force for his unappeased hatred. ${ }^{4}$

In one copy of a printed edition of the works of Horace, its student owner, who was attending a course on the Epistles taught in 1491, marked this passage with detailed manicule and inserted a handwritten note, squeezed between the text of poem and its commentary (Fig. 1):

Ista die $\mathrm{q}[\mathrm{ua}] \mathrm{n}[\mathrm{do}]$ lecta

fuit ista lectio [con]flixi

$\mathrm{cu}[\mathrm{m}] \mathrm{u}[\mathrm{n}] \mathrm{gare}$ padue

[...] $\left(221^{\mathrm{v}}\right)$

On the same day when this reading was read out, I had a fight in Padua with a Hungarian.

The student was Willibald Pirckheimer (1470-1530), who would later become famous as a leading German humanist and friend and collaborator of Albrecht

\footnotetext{
3 See for example Anthony Grafton and Lisa Jardine, From Humanism to the Humanities: Education and the Liberal Arts in Fifteenth- and Sixteenth-Century Europe, London, 1986. Robert Black, Humanism and Education in Medieval and Renaissance Italy, Cambridge, 2001, argued persuasively that the Italian teachers of the thirteenth and fourteenth centuries focused on points of language and showed minimal interest in moral instruction in their glosses and commentaries. Paul Grendler attributed greater importance to the role of moral teaching in Italian school education in the humanist period: "Moral admonition was such an integral part of Renaissance pedagogy that teachers could not be expected to pass up any opportunity to teach good morals' (Schooling in Renaissance Italy: Literacy and Learning 1300-1600, Baltimore, 1989, p. 232). But Grendler acknowledged that despite the humanists' general insistence on the moral utility of classical texts, there was a relative paucity of moral instructive remarks in the commentaries themselves. He argued that schoolmasters were expected to draw out the moral lessons in oral exchanges (ibid., p. 252).

4 Epistles I.2.59-61. The translation is by John Davie.
} 


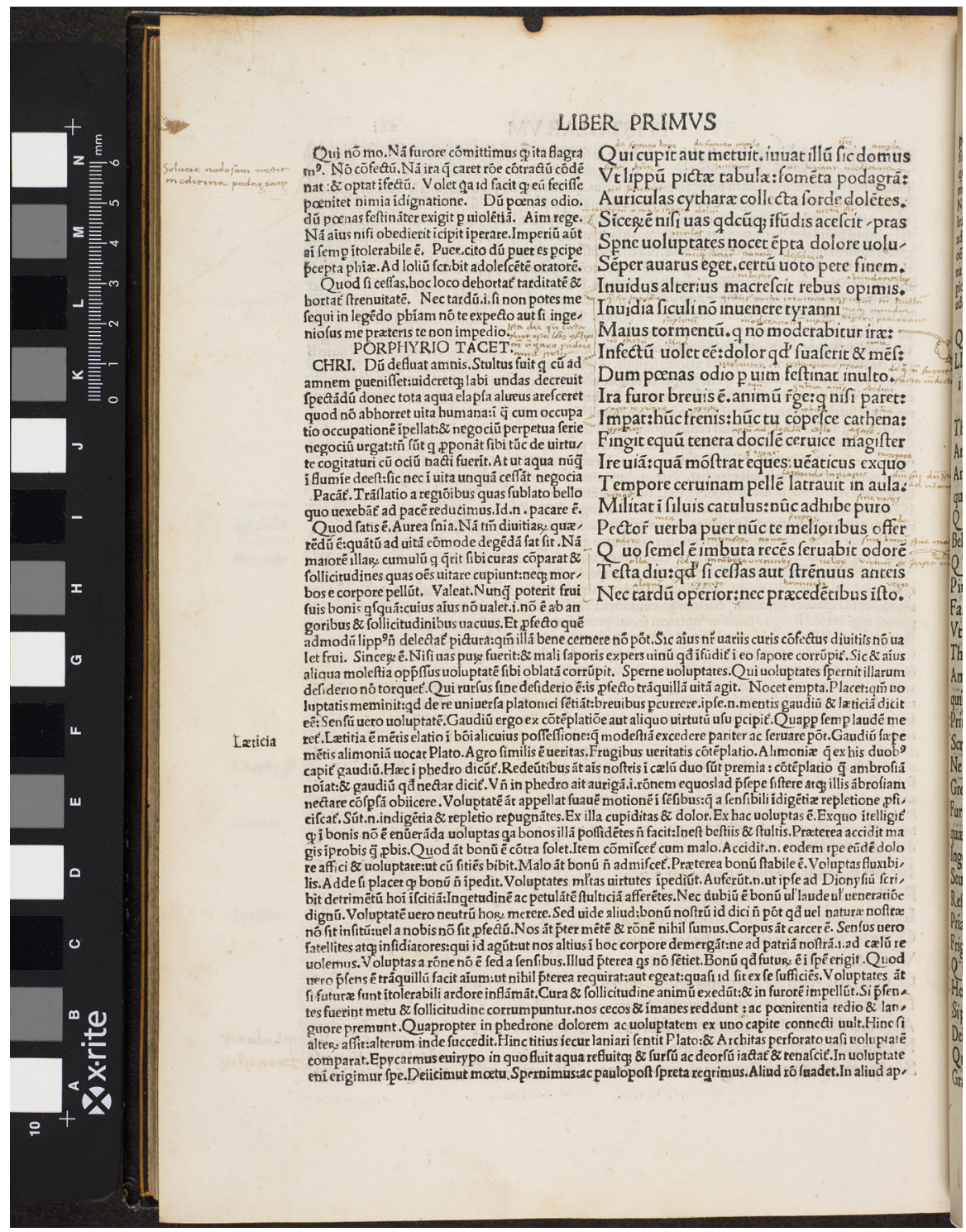

Fig. 1 Pirckheimer's note on Epistles I.2.59-61. Horace, Opera, Venice, 1490, fol. 221 ${ }^{\mathrm{v}}$. Rylands R214338. Copyright of the University of Manchester

Dürer; the teacher was Joannes Calphurnius (1443-1503), then professor of rhetoric at the University of Padua. The identity of the Hungarian is unknown: there were many at the university. ${ }^{5}$ What are we to make of this note? At first sight, not a great

\footnotetext{
5 An alternative interpretation of the note (given that we would expect 'cum Ungaro' rather than 'cum ungare') is that this is an abbreviation of a personal name: one possible candidate would be Joannes Antonius Ungarellus, whose presence in the law university at Padua is recorded for the year 1491
} 
deal. It does not suggest that the application of the moral lesson formed part of Calphurnius's teaching as he lectured: Pirckheimer noted that Calphurnius did a 'reading' of the lines, but he did not see fit to record its content; instead he jotted down his own little circumstantial note. Is the tone facetious? Defiant? Regretful? Is Pirckheimer using the classical sententia in some way as a lens through which to make sense of his own experience? It is difficult to judge in isolation. Whatever the story behind it, the note gives a tantalizing indication that there was more to the interactions between teacher, student and text than is generally revealed on the annotated page.

We might attempt to trace further the possible applications of the moral lessons furnished by poetry by looking at Pirckheimer's own literary productions from this period. His earliest surviving attempts at poetic composition also date from 1491, and they were also written by him in the margins of a printed book - in this case the Glossa ordinaria of Accursius. Under the title 'Carmina mea quae Paduae composui Anno Domini 1491' ('Poems composed by me in Padua in 1491'), Pirckheimer wrote:

De ira Disticon

Debilitat mentem, canos [sc. capillos] et provocat ira

Atque nocet cordi, displicet illa deo. ${ }^{6}$

On anger

Anger cripples the mind, and causes hair to go white

And harms the heart; it is a thing that displeases God.

We could speculate further on the possible connections between Pirckheimer's reading of Horace and his poem on the theme of anger as attempts to make sense of his own experience. But there is in the epigram no direct verbal echo of the Horace passage that caught Pirckheimer's attention as he read the Epistles with his teacher Calphurnius; and any connections must remain speculative. This example tells us little about the mechanisms whereby ethical teaching in the Renaissance classroom might carry through into an individual's life and writing. Indeed, the general absence of moral comment in the notes written by Pirckheimer as he followed courses on the hexametric poetry of Horace - precisely the kind of poetry where we might expect to find such commentary - rather suggests that the application of

Footnote 5 continued

(Fasti gymnasii Patavini, ed. J. Facciolati, Padua, 1757, for the year 1491: 'Jo. Antonius Ungarellus pridie id. Jan. electus est ad scholam tertiam Juris Civilis meridianam, quam tenuerat Jacobus de Leone'). A third alternative: this note must have been written before 1 August 1491, and a letter addressed by Pirckheimer to his father survives from precisely this period (July 1491), in which he mentions having come into conflict with the rector of the law students, identified as one Albertus Bavarus. See Willibald Pirckheimer, Briefwechsel, ed. E. Reicke, A. Reimann and H. Scheible, 7 vols, Munich, 1940-2009, I, p. 13, beginning: 'Bilibaldus filius Patri suo amantissimo [sic] S. P. D. Habui litteras vestras, Pater charissime, quibus scribitis simultatem inter me et Rectorem vobis displicere' ('Greetings from Willibald to his most beloved father. I received your letter, dearest father, in which you write that the dispute between me and the Rector displeases you').

6 The text of this and other poems that Pirckheimer composed at this time is reproduced in Pirckheimer, Briefwechsel (n. 5 above), I, p. 33. 
ethical lessons gleaned from the text was not at all a concern for his teachers. What, then, were they interested in?

The printed book in which Willibald Pirckheimer took down the note on Epistle I. 2 - a folio format single volume edition of the works of Horace, with the commentaries of pseudo-Acro, Pomponius Porphyrio and Cristoforo Landino (Venice: Georgius Arrivabenus, 1490) ${ }^{7}$ - provides an informative case study to answer this question. The book, which has never before been studied, is now in the John Rylands Library, Manchester (shelfmark: R214338). Pirckheimer's library stayed in his family until 1636, when it was bought by Thomas Howard Earl of Arundel, who was passing through Nuremberg on an embassy to the Emperor at Vienna. His grandson, Henry Howard the sixth Duke of Norfolk, was persuaded by John Evelyn in 1667 to present the library to the fledgling Royal Society. In 1873 the Royal Society sold off some of the books, and disposed of the remainder in 1925 at a Sotheby's auction. Our volume was among those sold in 1873 to the famous antiquarian bookdealer Bernard Quaritch. ${ }^{8}$ It came into the possession of Sir Edward Sullivan (1852-1928). Richard Copley Christie (1830-1901), a keen collector of Horace editions, acquired it from Sullivan, and on his death bequeathed his substantial library of early printed books to Owens College, later the University of Manchester.

A number of printed books annotated by Pirckheimer survive in various European libraries, including at least four annotated by him in the course of his studies with Calphurnius at Padua: this Horace edition, a 1488 edition of Cicero's Philippics, a 1488 De oratore now in the Germanisches Nationalmuseum in Nuremberg, and a 1490 Suetonius in the British Library. 9 The latter has been studied by Paolo Pellegrini. ${ }^{10}$ The Horace edition has never been studied and its whereabouts until now were unknown: the Christie catalogue compiled by Charles Leigh in 1915 included a fairly detailed provenance for the volume but for some reason failed to record the fact that it had been owned and annotated by Pirckheimer.

\footnotetext{
7 The Incunabula Short Title Catalogue and Gesamtkatalog der Wiegendrucke record the year of printing as either 1490 or 1491, because the date given in the colophon is 4 February 1490 ("Anno salutis.M.cccc. xc. Pridie Noū. Februa.'): i.e. 1490 if dated year beginning 1 January, and 1491 if dated 'more veneto', year beginning 1 March. The fact that Pirckheimer's notes on the Sermones are dated 1490 leads to the conclusion that the date given in the colophon is more likely to be the start of 1490 with the year beginning 1 January.

8 É. Offenbacher, 'La Bibliothèque de Wilibald Pirckheimer', La Bibliofilia, 40, 1939, pp. 241-63 (2501); M. Kerney, 'Bilibald Pirckheimer', in Contributions Towards a Dictionary of English Book Collectors as also of some Foreign Collectors, London, 1892.

9 These volumes, except for the Suetonius, were listed by Offenbacher, 'La Bibliothèque' (n. 8 above), pp. 253-4.

10 P. Pellegrini, 'Studiare Svetonio a Padova alla fine del Quattrocento', Incontri triestini di filologia classica, 7, 2007-2008, pp. 53-64. See also, by the same author: 'Giovanni Calfurnio e i commenti umanistici a Svetonio: filologia a 'margine' nella Padova di fine Quattrocento', in Libri a stampa postillati, ed. E. Barbieri and G. Frasso, Milan, 2003, pp. 231-266; and: 'Per gli incunaboli di Giovanni Calfurnio, umanista editore', Italia medioevale e umanistica, 42, 2001, pp. 181-283.
} 
The attribution of the annotations to Pirckheimer is beyond doubt, since he diligently wrote down at the end of each course his name, that of the teacher, the place and the date. The Odes, Satires and Epistles are annotated; the Epodes and Carmen saeculare are not; and the text of the Ars poetica bears only a few interlinear glosses on the first pages. At the end of the final book of Odes is the subscription: 'Calphur[n]io lege[n]te Bilibaldo pirckheymer op[er]a[m] dante Padue q[uin]to idi[bus] Augusti Anno 1492' (Fig. 2) ('Calphurnius gave the reading and Willibald Pirckheimer was in attendance, Padua, 9 August 1492'). At the end of the Satires we read: 'PADUE SUB RAPHAELE REGIO ANNO 1490' ('Padua, taught by Raphael Regius, 1490'). And after the final Epistle: 'SUB CALPHUR[N]IO PADUE AN[N]O 1491 in die festi petri ad ui[n]cula' ('Taught by Calphurnius, Padua, 1491 on the feast day of Saint Peter in Chains'). ${ }^{11}$

Pirckheimer, then, attended a course on the Satires given by Raphael Regius some time in 1490, a course on the Epistles given by Calphurnius ending on the 1 August 1491, and another - more advanced - course on the Odes, also given by Calphurnius, ending on the 9 August 1492. The two teachers who gave these lessons are well known. Joannes Calphurnius, Giovanni Calfurnio of Brescia, professor of rhetoric at Padua from 1486 until 1503, was, among other achievements, the author of the first humanist commentary on Terence to appear in print. ${ }^{12}$ Raphael Regius, best known for his massively successful commentary on Ovid's Metamorphoses, had held the same post before being forced out (he claimed) by the cunning machinations of Calphurnius. ${ }^{13}$ He must have continued to teach at Padua, where he was still living until 1492 when he returned to his native Venice. ${ }^{14}$ Regius hated Calphurnius with a passion, and more than once attacked him in print in imaginatively abusive terms: his 'In nonnullos errorum cuiusdam Calfurnii Bestiae Disputatio' (1490) ('Disputation on some of the errors of a certain Calphurnius Bestia') is a fine example of the vicious invective that was the currency of Quattrocento scholarly life. ${ }^{15}$

\footnotetext{
11 The Quaritch cataloguer had recorded the latter subscription (the basis for the listing by Offenbacher and for subsequent mentions of this volume), but had not noticed either the 1492 Odes subscription or the 1490 note mentioning Regius. Pellegrini, Per gli incunaboli (n. 10 above), p. 237, in tentatively attempting to date the courses of Calphurnius attended by Pirckheimer, is reliant on this incomplete information.

12 On Calphurnius, see J. Monfasani, 'Calfurnio's Identification of Pseudepigrapha of Ognibene, Fenestella, and Trebizond, and His Attack on Renaissance Commentaries', Renaissance Quarterly, 41, 1988, pp. 32-43.

13 'Suarum vero ineptiarum sibi conscius: cum virtute me loco depellere posse desperaret: ad insidias et dolos ac flagitiosissimas conspirationes confugit' ('Well aware of his own stupidity, and despairing of ever being able to force me out by merit, he resorted to strategems and deceptions and plots of the most disgraceful kind'). 'In nonnullos errorum cuiusdam Calfurnii Bestiae Disputatio' in Epistolae Plinii enarrationes, Venice, 1490 (sig.b4 ${ }^{\mathrm{v}}$ ).

14 C. G. Nauert 'Raphael Regius' in Catalogus translationum et commentariorum, ed. P. O. Kristeller et al., Washington DC, 1960-, IV, p. 338.

15 Calphurnius Bestia, 'Calphurnius the Beast', is a pun on the cognomen of the ancient Calphurnian family. Regius ridiculed Calphurnius (which was not his real name) for having chosen for himself such a pompous Latin name.
} 


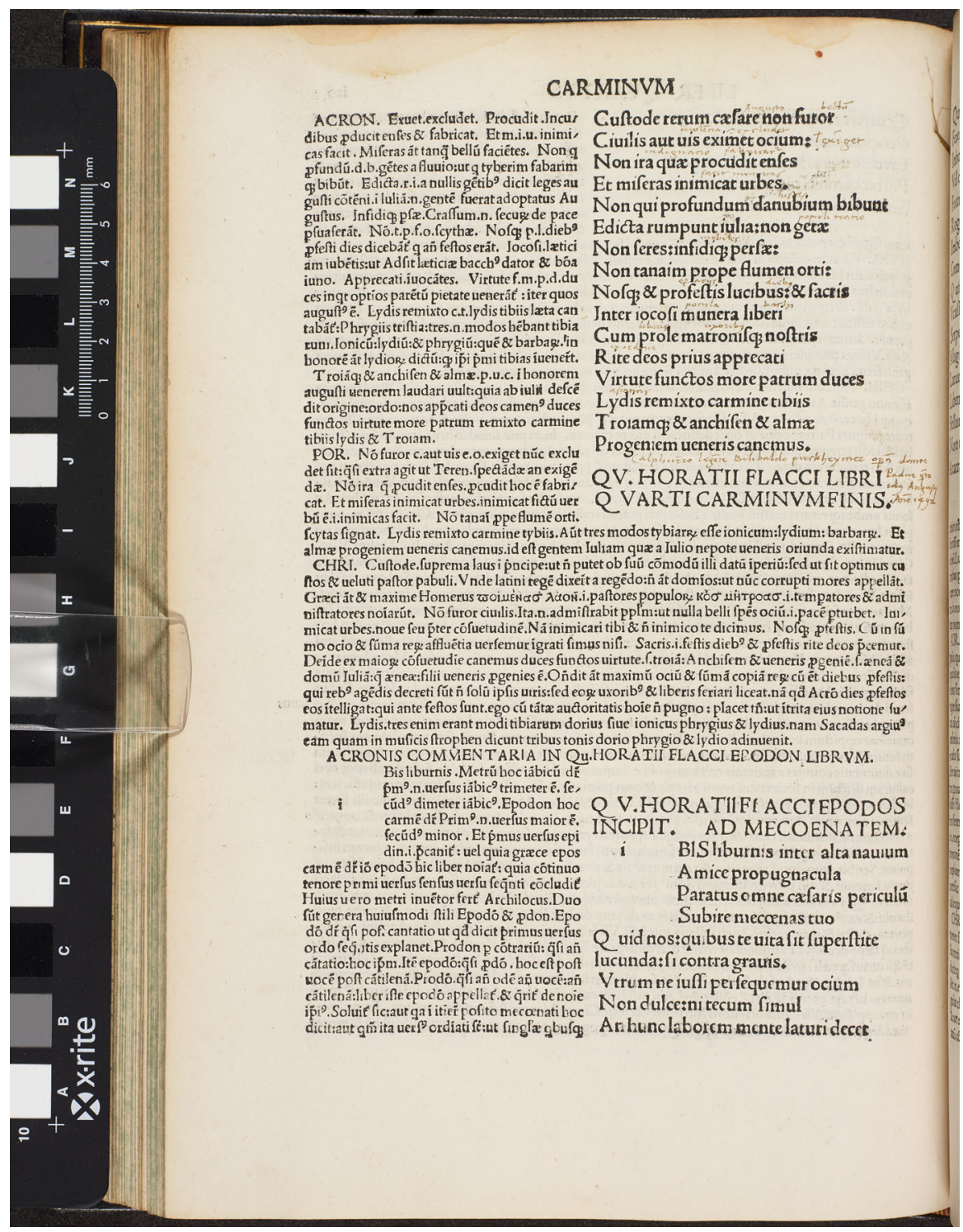

Fig. 2 Subscription to the Odes course: 'Calphur[n]io lege[n]te Bilibaldo pirckheymer op[er]a[m] dante Padue q[uin]to idi[bus] Augusti Anno 1492'. Horace, Opera, Venice, 1490, fol. 126' Rylands R214338. Copyright of the University of Manchester

The margins and interlinear spaces of early printed books preserve abundant evidence for teaching and reading practices. ${ }^{16}$ Alessandro Perosa and others have

${ }^{16}$ For a range of current approaches to the study of marginalia, see the two-volume collection: Talking to the Text: Marginalia from Papyri to Print, ed. V. Fera, G. Ferraù, S. Rizzo, Messina, 2002; and in particular the piece by M. Campanelli, 'Scrivere in margine, leggere il margine: frammenti di una storia controversa', pp. 851-939. 
made available editions of numerous unpublished commentaries by Poliziano, in some cases transcribing them from annotated incunabula, and from notes taken down by students who attended his lectures. In the Renaissance, the lessons of famous humanists might only make it into print through the intermediary of notes taken down by students. Editors and printers of such works often had cause to lament the inattentiveness of students whose error-strewn notes were the only surviving source for a lecture or commentary. The printer of an edition of some works by Pomponio Leto complained that the lecture 'De antiquitatibus urbis' had clearly been taken down in dictation by a student who did not know Latin well. The same printer, Jodocus Badius Ascensius, was able to print Girolamo Aleandro's comments on Ausonius in a 1513 edition only because he had access to the notes of one 'Homedeus', who had attended the lectures. ${ }^{17}$

Pirckheimer, for his part, seems to have been a fairly attentive and careful student; but the notes that this volume preserves are fragmentary and variable in length and interest. The variation is noticeable from text to text: the dictation of Regius on the Satires produces mainly brief interlinear glosses and very few longer notes in the margins. Likewise Calphurnius's lessons on the Epistles are mostly taken down in the form of short, densely written interlinear notes. The later course of Calphurnius on the Odes is different: as well as interlinear glosses of varying length and occasional marginal notes throughout all four books of Odes, the first book also includes some more substantial marginal notes, some of which serve as introductions to the poems with notes on their rhetorical classification and metrical features (Fig. 3). These introductory summaries, of between 5 and 20 lines, appear in the margin for most of the poems in the first book of Odes, but they decrease in length as it goes on, and disappear completely for the final few poems of the first book. None features in the second, third or fourth books of Odes, which contain more sparse interlinear glosses. The occasional longer glosses in the margins or surrounding the text at the centre of the page likewise become much sparser as the Odes go on. The decrease in the frequency and level of detail in the notes as the text of the Odes progresses is quite typical of such annotations: it is generally the case that beginnings of texts tend to be read more attentively and with greater enthusiasm than middles and ends; and the introductory material contained in the early summaries need not be repeated for the later poems.

This annotated book, then, will not furnish us with the 'lost commentaries' of Calphurnius and Regius on Horace. But it does offer a fascinating picture of teaching and learning in Padua in the late fifteenth century, a contribution to our understanding of the place of Horace's poems in humanist education, an insight into the ways in which printed books were used for the purpose of note-taking in the early modern university, and a snapshot of an early stage in the intellectual development of a major humanist author, editor and translator.

\footnotetext{
17 See White, Badius (n. 2 above), pp. 96-7; and Jean Letrouit, 'La Prise de notes de cours sur support imprimé dans les collèges parisiens au $\mathrm{XVI}^{\mathrm{e}}$ siècle', Revue de la Bibliothèque Nationale de France, 2 (June 1999), 47-56, which is also a very useful general survey of note-taking in the university context. Aleandro also instituted the practice at the University of Paris of designating a specific printed text for students attending his lectures to annotate.
} 


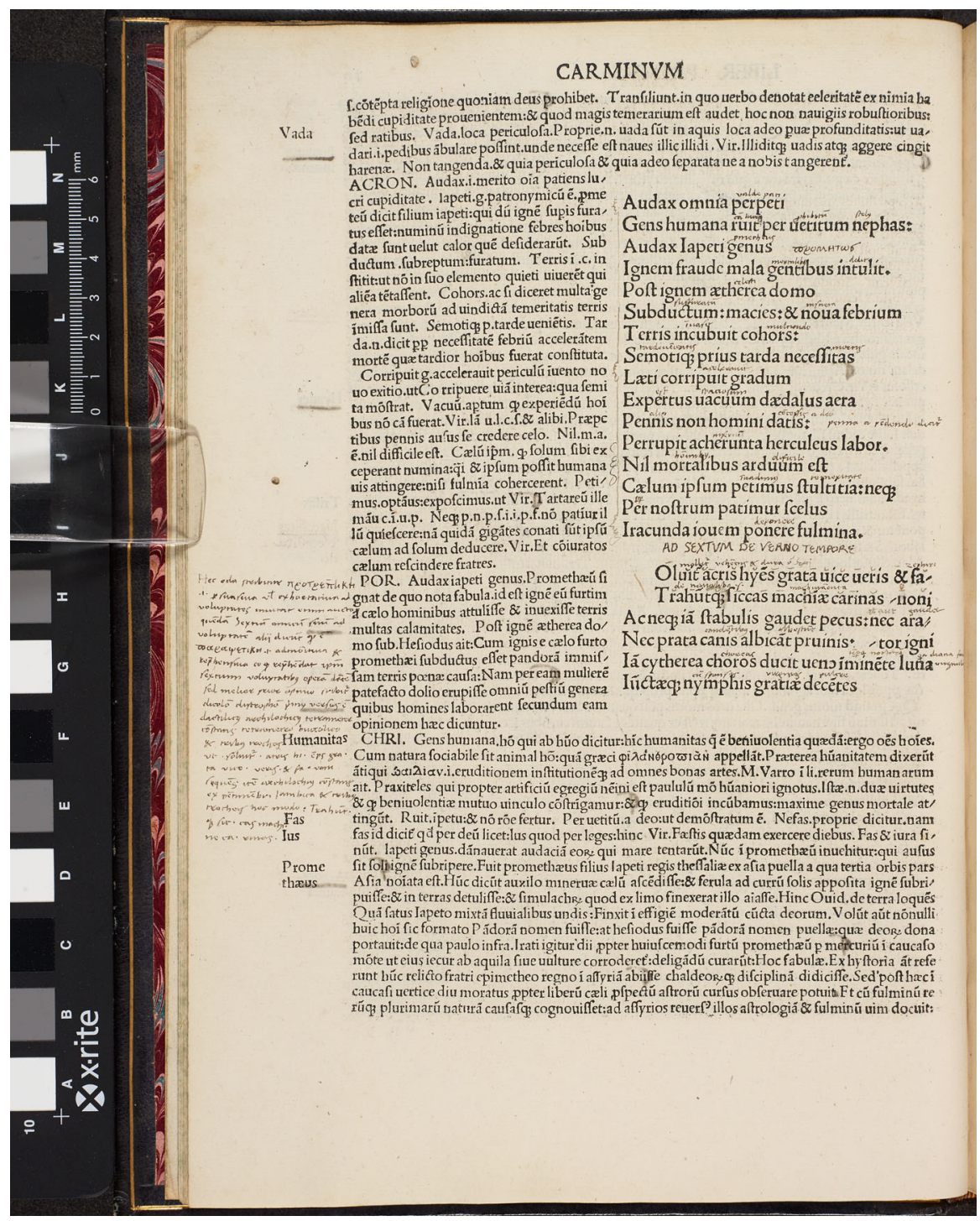

Fig. 3 Marginal summary and interlinear glosses. Horace, Opera, Venice, 1490, fol. 17 ${ }^{\mathrm{r}}$. Rylands R214338. Copyright of the University of Manchester

Between 1488 and 1492, Pirckheimer studied at the University of Padua. The University of Padua in the fifteenth century was in fact two universities, one of law and one of arts and medicine. ${ }^{18}$ Pirckheimer had come to Padua in 1488 at the age of

18 J. Woolfson, Padua and the Tudors, Cambridge, 1998, p. 3. On the university see also: P. F. Grendler, The Universities of the Italian Renaissance, Baltimore, 2002, pp. 21-40 and passim. 
18 to study law, but - according to the 1610 Vita of Pirckheimer compiled by Konrad Rittershausen - he had found the reading of the classics a more agreeable pursuit and neglected his legal studies, to his father's displeasure. This often repeated assertion has been disproved by the rediscovery of Pirckheimer's law notebooks from this time: he did indeed faithfully pursue his legal studies alongside humanistic pursuits. ${ }^{19}$

The Pirckheimers were an important Nuremberg family, but Willibald's early years had been spent mainly in Eichstätt and Munich; his was an itinerant youth, and he travelled widely with his father, Johann, holder of several important offices in Bavaria. Johann saw to Willibald's education personally: it was he who taught him Latin and read the major Latin authors with him. Johann Pirckheimer had himself had the benefit of an Italian education in the 1450s and 1460s, and had himself attended the University of Padua, where he obtained his doctorate in 1465. Manuscripts belonging to Johann and annotated by him, now in the Arundel collection at the British Library, show evidence of his humanistic learning: his marked preference for Roman poetry must have influenced the education he gave to his son. ${ }^{20}$ Among the MSS. annotated by Johann are the works of Horace (Arundel 239) and the Ps.-Acro commentary on Horace (Arundel 62). The hand used by Johann to annotate these texts bears some resemblance to Willibald's (more controlled) handwriting.

Johann's knowledge of Greek appears to have been minimal, though he did read a wide range of Greek authors in Latin translation. Holzberg suggests (p. 41) that study of the Greek language probably did not form any significant part of Willibald's early studies before his arrival in Padua - a suggestion that is borne out by the evidence from the volume that is the subject of this article. It was a point of the early biographies, and widely accepted by critics, that his education in Padua played a definitive role in forming Pirckheimer's intellectual interests, in particular his philosophical outlook - Rupprich emphasized neoplatonism - and his knowledge of Greek. The 1610 Vita of Pirckheimer says that he studied Greek at Padua under a teacher named 'Creticus' (in fact probably Laurentius Camers), but that Johann Pirckheimer discouraged his son's study of Greek, since it was of little use in law. The Vita also asserts that it was during his time in Padua that Willibald was inflamed with a love of Greek literature, and that he made such rapid progress in the study of Greek 'ut et Graecus ipse eius doctor admiratione duceretur' ('that even his teacher who was himself a Greek was impressed'). But the evidence from our volume dating from the end of Willibald's time in Padua suggests that this must be an exaggeration. The Greek in the annotations to the Horace volume rather tells the story of a student still at a tentative early stage of his Greek education. Indeed, as Holzberg concludes (p. 46), Pirckheimer's study of Greek in Padua under Camers was probably limited to the basics of grammar; his more profound knowledge of Greek was largely self-taught and dates from the years after his return to Nuremberg. It should be remembered that his first attempts at translation from

\footnotetext{
19 For this, and other details of Pirckheimer's early education, see: Niklas Holzberg, Willibald Pirckheimer: Griechischer Humanismus in Deutschland, Munich, 1981.

20 Ibid., pp. 38-41.
} 
Greek date from 1501-3, a decade after his studies in Padua, and his first published translation was printed in 1513 when he was 42 .

Were the courses on Horace given by Regius and Calphurnius public lectures or some form of private tuition? Calphurnius certainly lectured publicly on Horace at Padua around this time, in his capacity of professor of rhetoric, as Regius attests. ${ }^{21}$ Regius himself no longer held the post in 1490, but may have still been giving lectures. On the other hand, it seems entirely possible that these courses were extracurricular. ${ }^{22}$ Either way, the form and the content of the lessons, which are quite similar in the case of both teachers, typify the teaching methods of the grammar and rhetoric classes that had remained remarkably consistent for centuries in Italian schools and universities.

Less typical is the format of the book in which Pirckheimer took down these notes. It is a large format edition of the complete works of Horace which presents the text together with three commentaries: those of (pseudo-)Acro, Porphyrio and Cristoforo Landino. It is often assumed that large commentary editions were not generally used by students for the purpose of note-taking in school and university contexts. ${ }^{23}$ However, although it is the case that quarto and octavo formats were more commonly used in the classroom, ${ }^{24}$ there certainly is evidence for large format multiple commentary editions being used and annotated in various educational contexts. ${ }^{25}$ Pirckheimer's other annotated books dating from his studies in Padua are also folio format commentary editions. It is unlikely that most students would have owned such expensive editions, but Pirckheimer had an unusually generous book budget for a student: his father was a keen book collector and was sending him money to build up a library. ${ }^{26}$ Furthermore, the large format of the book did not necessarily make it less convenient for use as a notebook: rather than lugging a bulky hardbound volume into his lessons, it is possible that Pirckheimer was taking down the notes on the unbound leaves, which he later had bound. The book that has come down to us has been rebound, probably in the nineteenth century, and the margins have been trimmed, partially cutting off some of the notes, and concealing others in the binding.

How were printed commentaries used in this kind of course? We know from other examples of Renaissance school or university courses that the magister might

\footnotetext{
21 'In nonnullos errorum' (n. 13 above), sig. $\mathrm{C}^{\mathrm{v}}$, where Regius also mentions courses on Suetonius, Persius and Cicero.

22 Pellegrini, 'Studiare Svetonio a Padova' (n. 10 above), p. 55, tentatively suggests that that the Suetonius course given by Calphurnius and recorded by Pirckheimer in notes dated July 1492 may have been extracurricular. The fact that the wording in the subscription ('Calphurnio legente, Bilibaldo Pirckhaymer operam dante') is identical to that in our Horace edition suggests that the teaching situation was the same for both courses.

23 See for example J. Bloemendal, 'In the Shadow of Donatus: Observations on Terence', in Neo-Latin Commentaries and the Management of Knowledge in the Late Middle Ages and the Early Modern Period (1400-1700), ed. K. Enenkel and H. Nellen, Leuven, 2013, p. 313.

24 J. Letrouit, 'La Prise de notes de cours' (n. 17 above), pp. 47-56.

25 See for example C. Kallendorf, Virgil and the Myth of Venice: Books and Readers in the Italian Renaissance, Oxford, 1999, pp. 44-50.

26 See Pirckheimer's letter dated May 1491 in Briefwechsel (n. 5 above), I, p. 1.
} 
refer directly to the printed commentaries, or tacitly draw on them, in his oral explication of the text. In this case, the commentaries appear to have been largely ignored, almost ostentatiously so. Pirckheimer's annotations relate to the text of Horace and hardly ever engage with the commentaries. Clearly the edition being used by Pirckheimer was in no sense a 'set edition' being used by teacher and students alike: the teacher was working from a different text, and basing his comments not on the printed commentaries but on information he found in his own manuscript copy or copies (as we shall see). On the few occasions when Pirckheimer's annotations do relate to the commentary rather than directly to the text, it is Acro's commentary, rather than Landino's, that is being referenced. ${ }^{27}$ It should be mentioned that there are also some annotations of a different type that do show evidence of reading of the commentaries: in the Epistles and Ars poetica texts, written in a larger hand and in red ink, are index words in the margins highlighting points of information in the commentary (Fig. 4) - a very common type of annotation often found in early printed commentary editions. The hand resembles Pirckheimer's, but the identification is not certain. In any case, these notes have the appearance of having been added at a different time, and it is safe to assume that the commentaries were not being explicitly referred to in the lessons.

In 1490 Raphael Regius accused Calphurnius of incompetence, overweening arrogance and plagiarism; he attacked him for the poor quality of his teaching, for the incorrectness of his readings, and for his inability even to speak Latin except ineptly. But if we compare the course he gave on the Satires in the same year with that of Calphurnius on the Epistles in the following year, we can only conclude that this was a case of that familiar curse of academia, the narcissism of small differences (combined with no small measure of professional jealousy). For the notes taken down by Pirckheimer in both courses are remarkably similar to one another. In both cases they consist mainly of interlinear glosses, seldom expanding further than a few words of explanation, with very few marginal notes. The annotations to the Epistles are slightly fuller in places than those on the Satires, but they do not differ greatly.

As we have seen, despite the explicitly moralizing content of the Satires and Epistles, and the longstanding reputation of the satirical Horace as a moral authority, moral remarks are infrequent in Pirckheimer's notes to both collections. In fact, the predominantly grammatical and philological nature of the notes is quite typical of the ways these texts were read in Italian schools and universities. ${ }^{28} \mathrm{We}$ do find one set of notes of an explicitly moralizing nature in the annotations to the Epistles (listing the seven deadly sins, $217^{\mathrm{v}}$ ); but these notes, in black ink and in capital letters, appear to be in a different hand, or if written by Pirckheimer they must have been taken down at a different time.

\footnotetext{
27 Examples at fol. 1 ${ }^{\mathrm{v}}$, where the two marginal notes are positioned to answer Acro's notes on 'pulverem' and 'turba'.

28 Black, Humanism and Education (n. 3 above), pp. 26-7. See also Reynolds, Medieval Reading (n. 2 above): there was comparatively little moral comment in glosses on Horace's hexametric poetry from the twelfth century onward.
} 


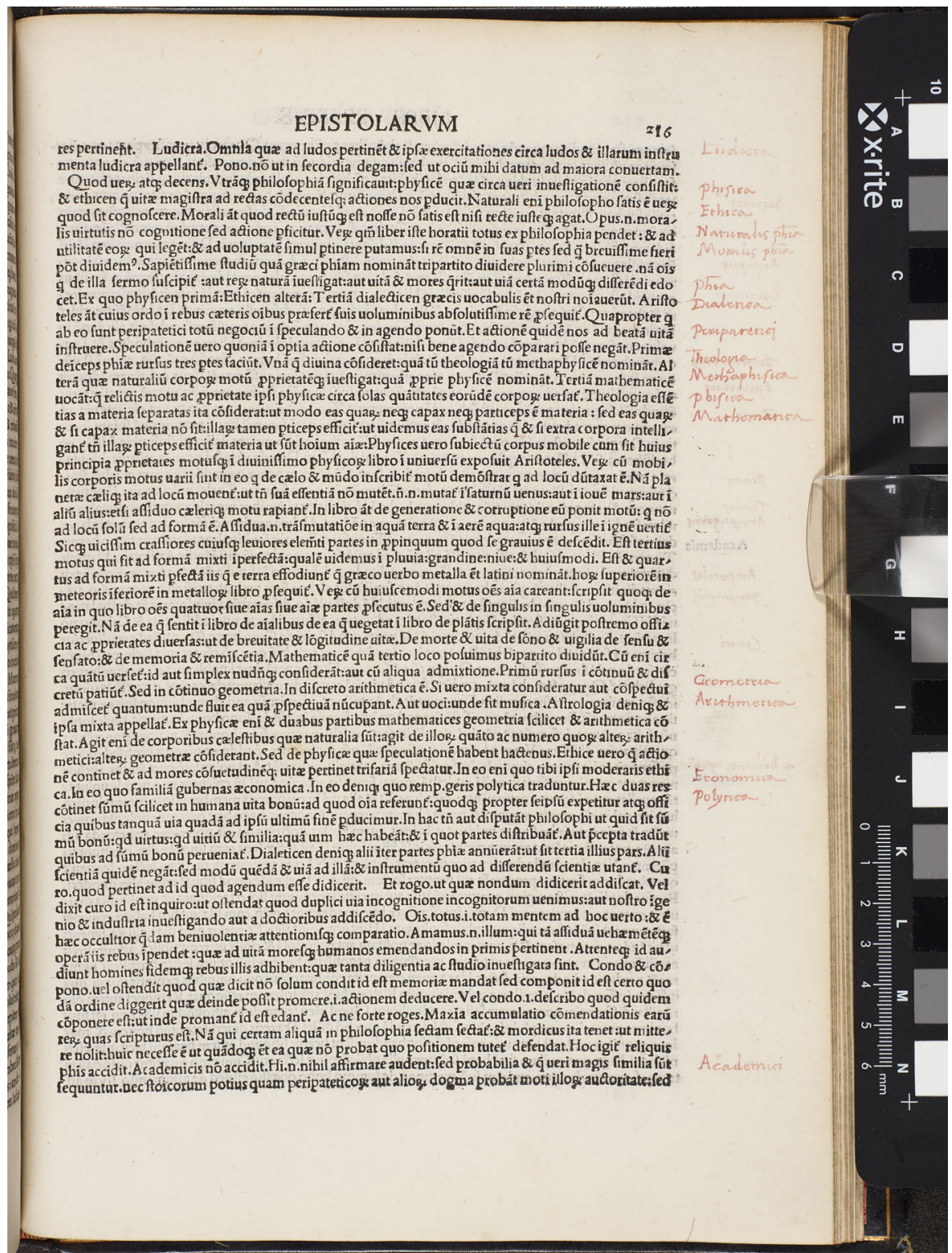

Fig. 4 Marginal index words in red ink. Horace, Opera, Venice, 1490, fol. $216^{\mathrm{r}}$. Rylands R214338. Copyright of the University of Manchester

The majority of the annotations taken down from Regius's dictation relate to basic comprehension and features of language. Pirckheimer's annotations on the Satires include a few Greek words identifying rhetorical and poetic features: e.g. $\pi \varepsilon \rho 1 \varphi \alpha \sigma[1 \varsigma]$

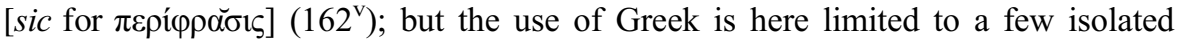
instances, contrasting with the much wider variety of Greek notes on the text of the 
Odes. Regius's textual readings are on the whole just as successful as those of Calphurnius on the Odes: the following emendations mark improvements to the text, based on a comparison with the modern critical editions: 'despiciant': 'desipiant' (II.3.47, 198 ); 'periret': 'at perisset' (II.3.93, 199 ); 'mutilus': 'mitilus' (II.4.28, 204 ); 'facile': 'facie' (II.4.71, 205v); 'intentus': 'at atentus' (II.6.82, 209 ${ }^{\mathrm{v}}$ ); 'externa': 'hesterna' (II.6.105, 210 $)$. Unsuccessful readings make up a much smaller number.

There are just three direct citations of authorities in the notes to the Satires: two quotations from Martial (one about lettuce (XIII.14), 205 ${ }^{\mathrm{r}}$; the other about the hours of the day (IV.8.1-6), $\left.184^{\mathrm{r}}\right)$; and one long marginal note $\left(212^{\mathrm{r}}\right)$ from Pliny, Natural History XXXV, $40 \S 126$, on 'Pausicas' (Pausias), a painter who mastered the technique of foreshortening. At Satires II.5.56 the notes identify a reference to the fables of Aesop ('respicit ad fabulam esopi', $207^{r}$ ). There is, again, little by way of interpretation of the content of the poems, except the occasional note of the type 'Superstitiosos per Libertinum reprehendit' ('he reprehends the superstitious through the character of Libertinus', 203 ${ }^{\mathrm{r}}$ ). But the Satires notes do pay attention to what might be considered useful, practical information. Horace's tips on what to look for when buying a horse at I.2.86-9 would have been of real value to a fifteenth-century student, and indeed Pirckheimer has written in the margin 'nota descriptionem equi pulcri' and drawn a manicule pointing out the passage $\left(169^{\mathrm{r}}\right)$. At Satires II.4.27-9 we read in the margin a note highlighting Horace's guidelines for good digestion ('praecepta ad digerendum', 204 ${ }^{\mathrm{v}}$ ). At I.1.36 the notes give the date when the Sun enters Aquarius ('febr. xviii cal. quo die sol intrat in aquarium', 163 ${ }^{\mathrm{v}}$ ).

Like the Satires notes, Pirckheimer's annotations on the Epistles are mostly of the interlinear gloss/paraphrase type. We see, again, a small number of Greek terms identifying textual features (e.g. ' $\pi \alpha \rho \varepsilon \mu 1 \alpha^{\prime}\left[\right.$ sic], $246^{\mathrm{v}}$ ); in addition there are also some more Greek glosses of the type seen in the Odes notes, including etymologies and Greek equivalents to Latin words. Calphurnius occasionally remarks on grammatical points and poetic usages (e.g. $223^{\mathrm{v}}$ 'singularem pro plurali'). Again, variant readings are given, sometimes marked by 'at' or '+'. There are, again, few references to other authorities: at one point the notes mention Cicero's Paradoxa for the Stoic view that vices are equal $\left(234^{\mathrm{r}}\right)$. On rare occasions, Pirckheimer has added numbers to indicate the word order (e.g. $245^{\mathrm{v}}$ ) - a technique that is obviously not needed as much for the hexametric poems as for the Odes. Again Pirckheimer has drawn manicules to point up sententiae: 'sapere aude' (I.2.40), 'mors ultima linea rerum est' (I.16.79); 'vilius argentum est auro virtutibus aurum' (I.1.52). One marginal note in particular is worth mentioning, given that its author would go on to compose the Praise of Gout (Apologia seu Podagrae laus): at $221^{\mathrm{v}}$ Pirckheimer has written: 'Solvere nodosam nescit medicina podagram' ('Medicine cannot soothe the knotty gout', in reference to Ovid, Epist. ex Ponto I.3.23).

The interlinear notes stop at Epistles I.12 and start again at I.15, which suggests that Pirckheimer missed a day's lessons at one point (and which in turn implies that if these were private extracurricular lessons, he was not the only student). We can surmise that after reading the Epistles with Calphurnius, Pirckheimer went on to begin the Ars poetica with him too: the text bears interlinear notes of a similar type, with a few Greek glosses (' $\pi \rho \varepsilon \dot{\pi} \omega v^{\prime}, 151^{\mathrm{v}}$ ) and identifiers of rhetorical/poetic 
features ('ipalage', 147 $7^{\mathrm{v}}$ ). The glosses stop at line 199, less than halfway through. Since the Ars poetica text also bears a small number of highlight words linked to the commentary, written in the same red ink as those found in the first book of Epistles if we accept that this too is Pirckheimer's hand - it seems likely that Pirckheimer was reading them at around the same time.

As Robert Black has demonstrated, in Quattrocento education interest in the works of Horace, whose hexametric poems had throughout the Middle Ages been in use as school texts, shifted in favour of the Odes. ${ }^{29}$ In the courses taught in Padua, it is clear from Pirckheimer's annotations that the Odes received closer attention than the Satires or Epistles, and that the commentary was of a more technical nature. This can be explained partly by the fact that lyric poetry invites more technical commentary than do hexametric poems, and partly by the fact that this was the final and therefore most advanced of the three Horace courses Pirckheimer followed at Padua: he completed it on 9 August 1492, a matter of weeks before leaving Padua on 13 September of that year. ${ }^{30}$

The longer marginal notes introducing each ode for most of the first book pay particular attention to rhetorical classification and to metrical analysis. ${ }^{31}$ On the first page (Fig. 5), Pirckheimer has taken down Calphurnius's general introductory remarks defining lyric poetry, calling Horace the greatest Latin lyric poet as Pindar was the greatest in Greek, and noting some Greek terminology. He then lists, in Greek, along with the equivalent terms in Latin, a number of rhetorical categories

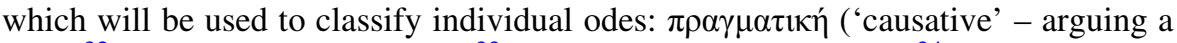

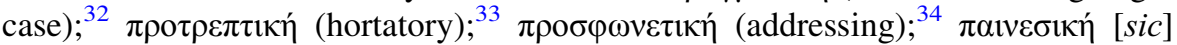

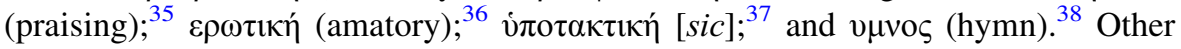

\footnotetext{
29 Black, Humanism and Education (n. 3 above), p. 246.

${ }^{30}$ For this date see Pellegrini, Per gli incunaboli (n. 10 above), p. 232.

31 See Black, Humanism and Education (n. 3 above), p. 318, on the growing interest in metrical analysis in the Quattrocento, associated with a rise in popularity of the Odes.

32 The category is applied to Odes I.1 $\left(1^{\mathrm{r}}\right)$.

${ }^{33}$ I.9 $\left(18^{\mathrm{r}}\right)$; I.11 $\left(19^{\mathrm{v}}\right)$; I.17 $\left(30^{\mathrm{v}}\right)$; I.18 $\left(32^{\mathrm{r}}\right)$.

34 I.12 $\left(21^{\mathrm{r}}\right)$.

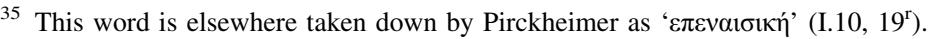

$36 \mathrm{I} .13\left(25^{\mathrm{v}}\right)$.

37 I.8 $\left(17^{\mathrm{r}}\right)$. The intended meaning of this word here, which in a grammatical context would mean subjunctive or subordinate, is far from clear; but in the context of Odes I.8 the word apparently relates to the 'subjected' lover's appeal to his domineering mistress. (I am grateful to the anonymous reader who suggested this interpretation.) Alternatively, it may be a mistake for ' translated as 'personaliter vel supponitive', appears in some MSS.

38 'Lirici poete apellant[ur] q[ui] carmina ad [...] chor[orum] et $\mathrm{p}$ [er]sona[rum] dabat[ur] [...] et dicti sunt lirici [a] lira Pindar[us] excellentissim[us] graior[um] fuit latinor[um] Horatius

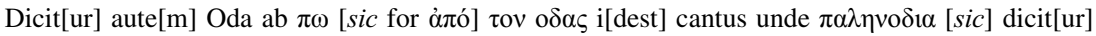
Inscribit[ur] q[ue] ob elegantiam $\pi \rho \alpha \gamma \mu \alpha \tau \iota \kappa \eta ' ;$

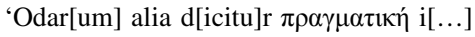

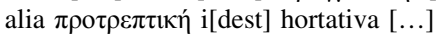


categories applied to individual odes include: ' $\pi \rho \sigma_{0} \alpha \tau \kappa \eta '$ ' - deprecativa' $\left(4^{\mathrm{v}}\right)$;

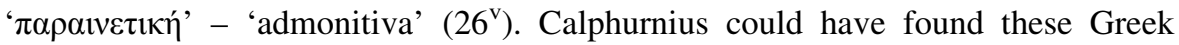
descriptors in many of the manuscripts of Horace's Odes, where they appear in the titles. Later in the sixteenth century Henri Estienne remarked on the inconsistency with which these labels, these 'epithetici tituli' as he called them, were applied to the poems in the manuscripts:

De illis autem vocabulis quae unicuique Odae in nonnullis etiam vet. exemplaribus praefiguntur, et illis velut epitheta quaedam tribuuntur, alius erit dicendi locus. Ea certe varia sunt: quum alia vocetur Pragmatice (ut quae primum in lib. I necnon quae in secundo locum obtinet) alia, Prosphonetice: alia Encomiastice: alia Paraeneticae: alia: Memptice: quaedam Euctice, sive Proseuctice: quaedam Erotice, quaedam etiam Syllogistice appelletur. ${ }^{39}$

Of these words that are set at the top of each ode in some of the manuscripts, including ancient ones, and are assigned to them like epithets [...] they are certainly varied: an ode might be called 'pragmatice' [...], another 'prosphonetice', another 'encomiastice', another 'paraenetice', another 'memptice'; another might be called 'eutice' or 'proseutice', another 'erotice', another might even be called 'syllogistice'.

As well as appearing in the titles of poems in the manuscripts, such categories were also sometimes applied by the commentators: they appear occasionally in the comments attributed to Acro. The latter, though, is not the source for Calphurnius's use of the categories, since Pirckheimer's notes do not precisely follow the labels given by Acro. Odes I.17, for example, called 'Parenetice' (hortatory) by Acro, is given the

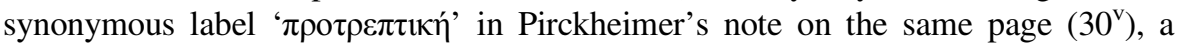
good example of the fact that the notes largely ignore the commentary. Calphurnius was taking the titles, which do not appear in the printed texts, from the manuscripts to which he had access, and he sometimes hesitates between different descriptors given to a poem in different manuscripts (see the introduction to Odes I.4 $\left(10^{\mathrm{v}}\right)$, quoted below).

Each of the odes in book one for which Pirckheimer took down introductory remarks is also given a fairly detailed metrical description. The following is a typical example:

$[\delta] 1 \kappa o ́ \lambda \tilde{\omega} \varsigma \tau \dot{\varepsilon} \tau \rho \alpha \sigma \tau \tilde{\omega} \varphi \varsigma_{\zeta}[s i c]$

$[\ldots]$

[C]omposita e[st] aute[m] car[m]ine saphic[o]

[...] car[m]en dictu[m] e[st] a sapho

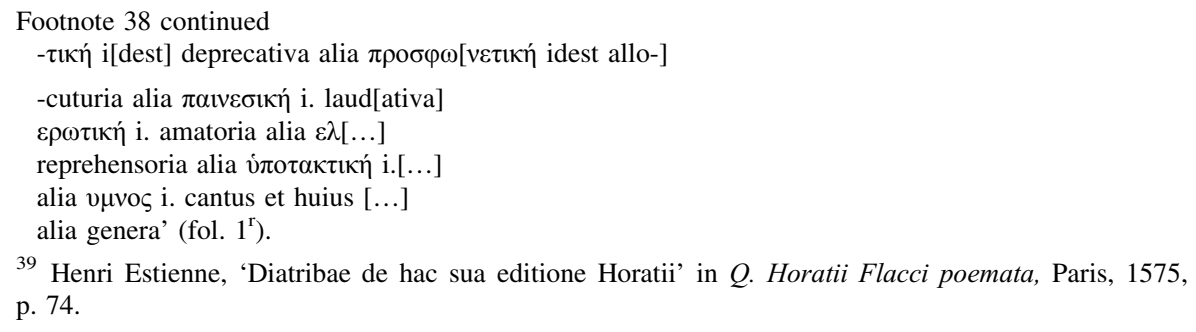




\section{OLIBER PRIMVS}

Eccenas atauis edite regibus. Hominú feribit officia pragmatice monocolos.ln cőmemora ACRON tione parentú a laudatio inuenitux:ut Virg.qui tắti talê genuere parếtes \& uituperatio. ut Ifmartas aut rhodope aut extremi garamantes (Edite regibus.qm̌ dicitur duxiffe originem ab ethrufcis regibus $\&$ côtempfiffe fenatoriam dignitatem:mâfiffe aút femper i equeftri or dine, 4 O \& præfidium.qú eú a cæde liberauit Bruto a Cxfare fuperato:uel quia p ip fum liberatus ể dine.

\section{TE REGIBVS. \\ O \&xprafidium $\&$ dulce decus meum}

magnalaus eft placere meliori.

TPORPHI. Meccenas atauis edite regibus Hac ode Mecoenatem alloquiê. Indicans aliú alio fudio teneri:eose qui appetantur lucri cu piditate uel gloria:fe putare aút inter deos $r$ latum iri fr tumero lyricoge poetarú afcript fuerit.Mecoenatem ait atauis regibus editum gr nobilibus ethrufcogt ortus fit.

CHRIS. Mecoenas,ad mecœnatẽ feribit cui ŏ̈tum debuerit pauloante in fua uita demöftranim?

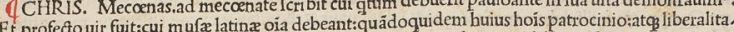
Et profecto uir fuit:cui mufa latinz oia debeant:quadoquid te pricipes poetage non folú fuftentati: tuegetia ad eas opes atç gaitate fubuectifntut ilhs inquier tiflimo ocio exclufa oi neceffítate igeniú excitare:\& in maximis rebus exercere fine cura licuerit.Qua propter omniú poematú: á a billis ad nos prouenerunt non folum auditoribus debitores fumus : fe ctiam illiper quem ipf hæc preftare potuerunt:cuncta debemus (Edite in lucem date.1. generate.F eni edo ex $8 z$ do. E i compofitiōe aliquâdo auget:ut eluceo ualdelluceo:aliquảdo uim babet prepofi $\mathrm{E}$ in con tionis ex tionis extra: tut etian róne dicimus edere manifeftare \& publicare. Vegz ego o lector iã a principio Edo edite nate. Eadem etiam róne dicimoccurrerent enodanda uocabula:ea me primo femper loco diligen hoc monitú te efle uelim:me quæ occurrés fuas notiones traductugz:ne rurfus alio in loco idem frepius re rer interpratatug: $\&$ abfolute ut per oes fuas notiones tra forte iam exciderit: inuenies omnium ídices petendum fit.Quod fi tibi cum itegy occurret:memoria forte iam exciderit: inuenies omnium idices ex ordine litterage in ultimo codice pofitostut inde ueluti ex perểni fonte i tuos ufus haurire polfis. Sed răfeo ad reliộ. A A tauis regibus.laudat a genere: Sic Vir, Dardanid $x$ duri.ltem nate dea:nả te maio ribus ire per altú. Aufpiciis manifefta fides:fic côtra uituperauit. V t bellum etiä pro cæe de boú:ftratifọ iuuencis laomedontiadx. Praterea magna auxeft uftus eft:qui dixerit atauis regibus. Non.n.folum no bilitatem: uegetiā uetuftatể in nobilitate laud auit.P raclagrení munus fortunæ eft nafci ex rege: fed $\tilde{e}$

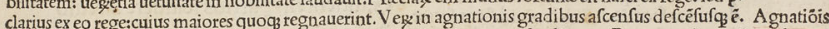
clarius ex eo rege:cui us maiores quoqz reguatré appelles: fiue is a patrădo dicatur. Patrare ení operä gradus Afcêditur aút hoc pacto:ut qui te genuerit patrẻ appelles:fiue is a patrădo dicatur. Patrare ení operá gradus

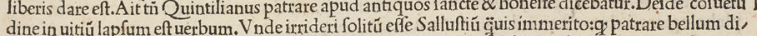
xerit: tang̈ patro rể turpể dútaxat fignificet. Hæc Quintlianus. Ex quibus ucrbis colligitur prifcos pa, trare pro perficere 8 finire pofuiffe:nó folum cum liberis opa daretur. Vegretiâ cú aliuad quidpiam iâ

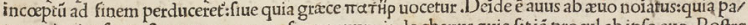
tre antiquior fit: poft aum paus:quafi ppe aumm.inde abauus quia fit iả procul ab ipfo auo. Poftre món quior fit: poft atro

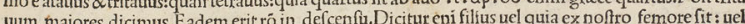
uum maiores dicimus. Eadem ert rô in . Nibil cni magis amat pater $\mathrm{g}$ filiü.inde nepos quafi natus poft ab amore:qui grace pi folum dicit ; qui eft ex filio natus:ueg ex filia $\&$ ex fratre $\&$ ex forore: iccirco adiungimus Speufippus nepos $\mathrm{P}$ latonis fuit ex forore $T$ uliola neptis fuit $\mathrm{Qu}$.Ciceroni ex fratre. Qui uero polt trinepotê funt: minores appellant,. Ex lateralibus aút bểmus patruú patris fratré $\mathscr{E}$ auuncul um matris fratrem. Qui aút aui frater fit: quifi gua matertera dicitur. Eft frater quia fere fit alter tu. Eft foror quia feorfum a fua firpe nata nideatur $\$ z$ afii ftirpi adiügenda. Sunt patrueles ex duobus fratribus nati:qmĭ qui pater alteri eft: alteri eft patru? Sunt itidem cófobrini quafi cōfororini ex duabus orti fororibus aut ex forore \& fratre. Denigg gentile \&z agnati dicútur oếs qui funt ex eadẽ ftixpe mafeulina. Cognati nero quoozz maternum geñus idẽ fit. Affines poftremo qui non tibi natura:fed uxori tux cötúfai funt.uxor ip fa dicitur:quia ut foror tibi effe debeat: uel uxor quafi unxor ab ungendo:quia apud pufcos noux nuptx ungerentur.Maritus dicitur quia mas fit.inde in cöiugio focep dicimus \& focrum:quia fi bi genegz affocient. Gener aút ex eo eft generandi cá affumitur. Nurus uero quia nubat $\bar{O}$ \& præfidium \& dulce decus meum. Laudauerat a nobilirate quod bonum fortunæe ê. Sed quoniấ fortunæ dona non bona funt:ut ftoicis placet: quia non propter fe expetútur:fed ut per illa aut humanả neceffitatemppulfemus aut cömodius ad uirtutẻ

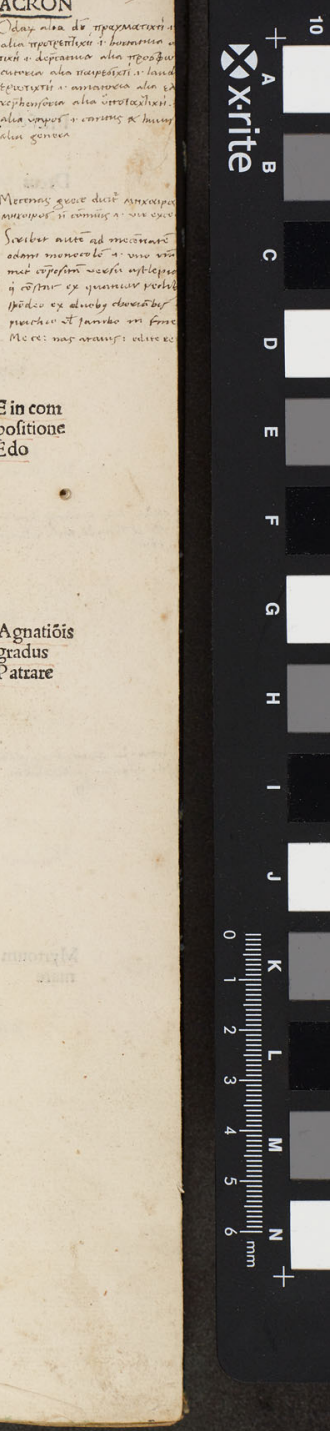

Fig. 5 Annotations at the beginning of the Odes course. Horace, Opera, Venice, 1490, fol. $1^{\mathrm{r}}$. Rylands R214338. Copyright of the University of Manchester

[...] quada[m] poetride q[uae] fuit

[inv]e[n]trix huius car[m]inis: et e[st] dicolos

[tetra]strophos i. bi[m]embris et h[abe]ns duo

[gen]era metror[um] tria enim prima

[m]etra saphica sunt [] vero 
[Ad]oniu[m]: constat aute[m] hic versus

[quinque] pedibus trocheo spo[n]deo dactilo

[tro]cheo et spo[n]deo vel trocheo ut

[ia]m sa: tis terr: ris nivis: atque

[di]rae: ultimu[m] e[st] adoniu[m] co[n]stans

[d]actilo dimetra catalectica hoc e[st]

[d] actilo et spondeo vel trocheo $\left(4^{\mathrm{v}}\right)$

The ode is composed in Sapphic stanzas, named after a poetess called Sappho who was the inventor of this poetic form. It is 'dicolos tetrastrophos', which means double-membered, having two kinds of metre. The first three lines are in Sapphic metre, but [the last] is Adonic. This verse, then, consists of five feet: a trochee, a spondee, a dactyl, a trochee and a spondee or trochee, as in: 'iam sa: tis terr: ris nivis: atque : dirae'. The last line is Adonic, consisting of dimetric dactylic catalectic, which means a dactyl and a spondee or trochee.

Here the notes on metre are fairly similar to those in Acro's commentary. In general, the interest in metre does not appear to extend very far into the reading of the text itself: Pirckheimer has inserted scansion marks at some points $\left(10^{\mathrm{v}}, 19^{\mathrm{v}}\right)$, but these are very infrequent.

Pirckheimer also adds descriptive titles for individual odes, again presumably taken from manuscripts ('De Recessu Virgili amici sui' ('On the departure of his friend Virgil', I.3); 'De Laudibus hominum et deorum' ('Praise of men and gods', I.12)). The rhetorical description of the poems also often contains a brief summary of their content:

\section{Ad Lidia Meritricem [sic]}

Hec oda scribit[ur] ن்

[con]tra quanda[m] lidia[m] m[eretricem]

quam ip[s]e olim amaverat rep[re]hen[dat]

q[uod] se neglecto receperat sibar[im]

$[\ldots] \mathrm{eu}[\mathrm{m}]$ devinxerit ut [neglexit] [...]

omnis honesti exercit[ationis] [...] $\left(17^{\mathrm{r}}\right)$

To Lidia, a courtesan

This ode is written 'hypotactice' [...] against a courtesan called Lidia whom the poet once loved. He reprehends [her] because after rejecting him she took up with Sibaris [and] overcame him so that he neglected the [pursuit] of all good discipline

Again this is broadly similar, though not identical, to the summary found in Acro.

The introductory notes sometimes contain brief, basic remarks on poetic features in addition to the rhetorical classification:

Ad Rem. P. Seu Ad Mar.

Brutum

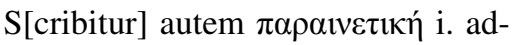


monitive admonet eni[m] re[m] pu[blicam]

romana[m] sub metaphora navis

seu poti[us] ei[us] ductore[m] et defe[n]-

sorem M. Brutu[m] sub quo mili-

tavit horatius: ut semel

victus a cesare augusto non

iter[um] reparet exercit[us] Tota e[st]

[...] metaphorica seu alegorica $\left(26^{\mathrm{v}}\right)$

To the Republic, or, to Marcus Brutus

It is 'parainetice', which means hortatory. He advises the Roman Republic using the metaphor of the ship; or rather he advises its leader and defender M. Brutus, under whom Horace fought, that once defeated by Augustus Caesar he should not raise armies again. The whole is metaphorical or allegorical.

More rarely the notes address problems of interpretation via the question of their rhetorical classification:

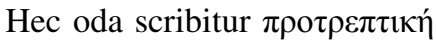

i[dest] suasiva vel exhortativa ad

voluptates[.] invitat nam auctor

que[n]da[m] Sextu[m] amicu[m] suu[m] ad

voluptate[m][.] alii dicu[n]t q[uod] e[st]

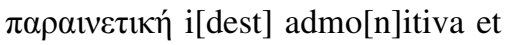

rep[re]hensiva q[uod] rep[re]he[n]dat ip[su]m

sextum voluptatib[us] opera[m] da[n]te[m][.]

sed melior prior opinio $\left(10^{\mathrm{v}}\right)$

This ode is 'protreptice', which means suasive or exhorting to pleasure. For the author invites a friend of his named Sextus to take pleasure. Others say that it is 'parainetice', which means admonishing and reprehending, because he reprehends Sextus for giving attention to pleasure. But the first opinion is better.

This is one of the only points in Pirckheimer's notes that actually addresses a problem of interpretation in the poems. Little attention is paid to such matters throughout the notes, and this example demonstrates a distinct lack of interest in making Horace's poems conform to an edifying moral framework (a lack of interest shared by most of the humanist commentaries, which do not attempt to force on this poem an interpretation other than that it is an Epicurean celebration of fleeting pleasures).

For our purposes the interlinear annotations to the Odes are largely uninteresting, since they are for the most part composed of notes designed to aid basic comprehension of the text. These very much conform to the standard mode of reading classical Latin authors in Italian schools and universities, which, as Black showed, hardly changed throughout the period from the twelfth to the fifteenth century. ${ }^{40}$ These notes consist of straightforward synonyms or definitions, and

${ }^{40}$ Black, Humanism and Education (n. 3 above), pp. 275-86. 
clarifications of syntax, supplying final verbs, the antecedents of pronouns, etc. They also identify persons and things referenced but not named by Horace, usually not expanding any further than a one-word identification. Sometimes, but not often, they paraphrase more fully for clarity. There are occasional longer notes on the usage and meaning of expressions. ${ }^{41}$ There are notes on the etymologies of words, sometimes extravagant: one suggests that 'castra' ('camp') comes from 'casta' ('chaste') since the ancients were not permitted to bring prostitutes into them. ${ }^{42} \mathrm{We}$ also occasionally see annotations marking the word order: numbers written above words to give the ordo naturalis. ${ }^{43}$ There are a handful of examples in the text $\left(1^{\mathrm{v}}\right.$, $\left.31^{\mathrm{r}}, 76^{\mathrm{r}}, 92^{\mathrm{r}}, 99^{\mathrm{v}}\right)$ : this method is not applied systematically throughout, either because the magister only used it for passages that were particularly difficult syntactically, or because Pirckheimer did not need to take such basic notes except for those passages.

But it is not only basic linguistic glosses that feature in the interlinear and marginal notes on the Odes. In what follows I shall briefly discuss the other main types of annotation. Other than the basic gloss, the most prominent type of note identifies grammatical, rhetorical or poetic features. ${ }^{44}$ These tend to be one-word or concisely phrased notes in the margins of the main text identifying basic features with no analysis: 'Sinecdoche' $\left(6^{\mathrm{r}}\right)$; 'diminutivum' $\left(30^{\mathrm{v}}\right)$; 'metaphora' $\left(11^{\mathrm{r}}\right)$; 'ambiguum' $\left(13^{\mathrm{v}}\right)$; 'antonomasia[m] posuit' $\left(31^{\mathrm{r}}\right)$; 'hiperbaton' $\left(47^{\mathrm{v}}\right)$; 'repetitio' $\left(55^{\mathrm{v}}\right)$; 'Alegoria' $\left(97^{\mathrm{v}}\right)$. Frequently these are in Latin, although there is also a significant number of rhetorical and grammatical terms in Greek ( ' $\pi \varepsilon \rho \eta \varphi \rho \alpha \sigma \eta \varsigma^{\prime}$ [sic], ' $\varepsilon \pi \eta \theta \varepsilon \tau o v '$ [sic] (4 $\left.{ }^{\mathrm{v}}\right)$;

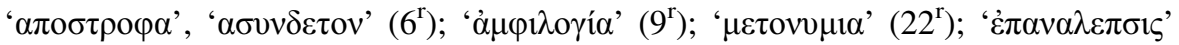
$\left(72^{\mathrm{r}}\right)$; ' $\zeta \varepsilon v^{\prime} \gamma \mu \alpha$ ' $\left.\left(78^{\mathrm{r}}\right)\right)$. Although this was notionally a rhetoric course, there is just as much basic grammatical as rhetorical comment, and there is very little by way of extended rhetorical analysis. Many annotations are more geared towards basic comprehension than rhetorical points for imitation: for example those marking the speaker ('verba Iunonis' $\left(80^{\mathrm{r}}\right)$; 'verba lydie', 'verba horatii' $\left(91^{\mathrm{v}}\right)$ ). The more clearly rhetorical remarks focus on figures and arguments ('ista est lamentatio' $\left(39^{\mathrm{r}}\right)$; 'exclamatio' (86 $6^{\mathrm{v}}$ ); ‘Argumentatur ab exemplo' $\left(93^{\mathrm{r}}\right)$; 'Ab exemplo' $\left(97^{\mathrm{r}}\right)$ ) and tone ('quasi delectans dicitur' $\left(4^{\mathrm{r}}\right)$ ). Only rarely do the notes highlight effective poetic technique, e.g. 'Expressit naturam flammae' $\left(122^{\mathrm{v}}\right)$.

The frequent use of Greek is the most striking feature of the annotations on the Odes. As well as rhetorical terms, Pirckheimer adds other glosses in Greek: some are

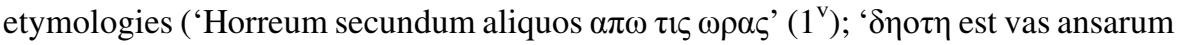
a $\delta 1 \sigma \alpha$ bis $\omega \varsigma \omega \tau$ o ansa' $\left.\left(18^{\mathrm{v}}\right)\right)$; others are simply transliterations in Greek characters of

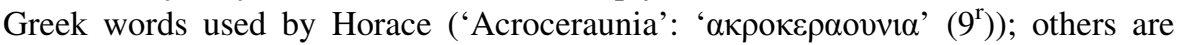
translations into Greek or Greek equivalents of Latin words ('oceano': $\omega \kappa \varepsilon \alpha v o \varsigma\left(9^{\mathrm{r}}\right)$;

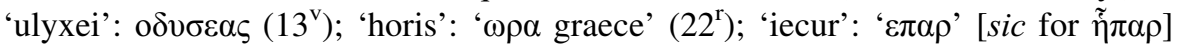

\footnotetext{
${ }^{41}$ E.g. at fol. $110^{\mathrm{r}}$ a note to 'in diem...vixi' reads: 'in die[m] vivere e[st] q[ui] $\mathrm{n}$ [on] h[abe]t ratio[n]em seque[n]tis diei'.

42 'Castra dicuntur quasi casta q[uod] antiquis n[on] licebat in ea ducere scorta' $\left(3^{r}\right)$. Similar explanations are given by Servius and Isidore.

${ }^{43}$ Cf. Black, Humanism and Education (n. 3 above), pp. 281-3.

44 Ibid., pp. 286-8.
} 
$\left.\left(39^{r}\right)\right)$. Pirckheimer, who owned a copy of the 1488 editio princeps Homer in Greek, also noted down in his Horace edition some Homeric epithets: for example at Odes III.4.60 'nunquam umeris positurus arcum' ( $84^{\mathrm{v}}$ ) he writes 'á $\rho \gamma \nu \rho o \tau o \xi[o \zeta]$ ' ('with silver bow', epithet of Apollo); and a few lines later, at 'centimanus gigas',

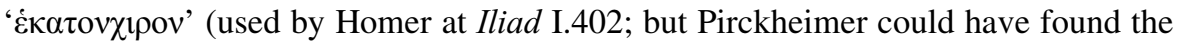
word in Landino's commentary). These Greek glosses are not only there to aid comprehension of Horace's text: rather, Pirckheimer is using the text of Horace as a basis for practising and learning his Greek, albeit in a limited way. Pirckheimer, who would become an accomplished Hellenist and translator of Greek, was - as we have seen - in 1490-2 a student at a relatively early stage of his Greek education. His Greek in these notes is hesitant, and marred by quite frequent errors of the type to be expected from such a student taking down notes at dictation speed. It would appear that Calphurnius in his lessons was not expecting his student to attend closely to the correctness of the Greek characters. Moreover, given that the majority of Greek words that appear in the notes are isolated words taken directly from the MSS. sources or from the commentaries, it seems that Greek was an accessory element and not a central preoccupation of his teaching.

Few authors are cited directly in the notes taken down by Pirckheimer. The names that do feature are mainly there to authorize points of information (rather than, say, providing parallel examples of poetic or rhetorical technique). Pliny the Elder is the authority that features most often, in notes on the riches of Attalus $\left(1^{\mathrm{v}}\right)$; on the linden-tree $\left(51^{\mathrm{r}}\right)$; on sheep $\left(58^{\mathrm{v}}\right)$; on Mercury $\left(92^{\mathrm{v}}\right)$, on the Delphic laurel, $\left(111^{\mathrm{r}}\right)$; on the word 'adorea' $\left(117^{\mathrm{r}}\right)$. Plato is cited more than once $\left(99^{\mathrm{v}}, 100^{\mathrm{r}}\right)$; Cicero, once $\left(1^{\mathrm{v}}\right)$; Plautus, once $\left(103^{\mathrm{v}}\right)$. Excerpts from other poets are for the most part conspicuous by their absence; an exception is a long passage from Manilius, Astronomicon I.73-90 transcribed in the margin of Odes I.3 $\left(9^{\mathrm{r}}\right)$, a parallel to Horace's reference to the invention of sea travel. It is likely that this was added by Pirckheimer at a different time, and was not part of Calphurnius's dictation: indeed he owned an edition of the Astronomicon of Manilius printed in Venice or Verona in 1489 or 1490 , from which the passage appears to have been transcribed. ${ }^{45}$

The other marginal notes of any length mainly relate to points of mythology and history. At fol. $6^{\mathrm{r}}$ for example Pirckheimer writes: 'Ilia filia fuit numitoris q[uae] $\mathrm{cu}[\mathrm{m}]$ ex marte $\mathrm{p}[\mathrm{re}] \mathrm{gna}[\mathrm{n}] \mathrm{s}$ esset ab amulio in tiberim proiecta e[st] et ideo dicta e[st] uxor tiberis' ('Ilia was the daughter of Numitor. When she became pregnant by Mars she was cast into the Tiber by Amulius and is therefore called bride of the Tiber.') Again, the source for this note appears not to have been any single commentary, but all of the details could have been pieced together from Acro and Landino. There are some odes such as I.10 whose mythological content prompts longer marginal notes: one recounting the story of how Mercury invented the lyre

\footnotetext{
45 Kerney, 'Bilibald Pirckheimer' (n. 8 above), p. 5; Offenbacher, 'La Bibliothèque' (n. 8 above), pp. 254-8. The passage transcribed from Manilius is identical to the text of this $1489 / 90$ edition, except for the line 'Sed qum longa dies acuit mortalia corda', which Pirckheimer has transcribed as 'Sed cum longa dies mortalia acuit [corda]'. None of the other editions has this reading, which appears to be merely the result of inattentive copying on the part of Pirckheimer, since it does not scan properly. Pirckheimer also owned Ficino's translations of Plato (Florence 1483-4), which he probably bought in 1490, as mentioned in a letter to his father: see Briefwechsel, I (n. 5 above), p. 1.
} 
using a tortoiseshell and strings made from the hides of the stolen cattle of Apollo $\left(19^{\mathrm{r}}\right)$; and another on the following page about the caduceus $\left(19^{\mathrm{v}}\right)$.

The other major category of annotations made by Pirckheimer is the insertion of variant readings and corrections to typographical errors in the printed text. These are distinguished from the other interlinear notes by being written in a studiedly different hand, larger and neater, sometimes crossing out the word in the printed text and writing in the improved reading, sometimes not crossing out; and sometimes scratching out the incorrect reading and writing over the top (see, e.g., I.25.10 (38 ${ }^{\mathrm{r}}$ ): 'levis' for what was apparently 'lenis'; I.28.22 (42 $)$ : 'comes' scratched out and the correct reading 'nothus' written in). The following are some examples of the insertions and corrections Pirckheimer makes to the text: 'Sidera fulgent': 'at Stella refulsit' (I.12.28, 22 ${ }^{\mathrm{r}}$ ); 'coniiciat': 'at iniciat' (I.17.26, 31 '); 'umbra': 'at aura' (I.22.18, 36 ${ }^{\mathrm{r}}$ ); 'cibis': 'at tibi' (I.25.13, 39 $)$; 'temnis': 'tendis' (I.29.16, 43 ${ }^{\mathrm{r}}$ );

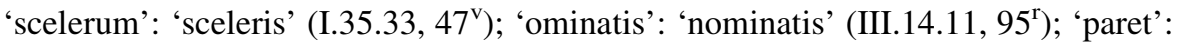
'petet' (III.19.14, 99 ); 'dixit': 'al duxit' (IV.2.59, 114 ${ }^{\mathrm{r}}$ ); 'monstro': 'monstror' (IV.3.22, 115 ); 'nixus': 'nisus' (IV.4.8, 115 ). They are sometimes marked by the word 'at', abbreviating 'alii legunt', sometimes by '+' (e.g. 'pius Aeneas': '+pater' (IV.7.15, 119 $)$ ).

It seems Calphurnius had access to much better manuscripts than the editor of the 1490 Venice edition (one Johannes Franciscus Philomusus), since the majority of readings noted by Pirckheimer are improvements: all of those listed above, with the exception of the last, are in line with the modern critical editions. ${ }^{46}$ Overall the annotations significantly improve the text, correcting both printing errors and faulty readings. ${ }^{47}$ Evidently not all of the readings suggested by Calphurnius rely on manuscript authority alone, as is demonstrated by the few instances where Pirckheimer has taken down a note explaining the reasons for a preferred reading. Noting the variant 'candentis' for 'candenti' at Odes I.2.31 (6 $\left.6^{r}\right)$, he writes: 'Candenti meli[us] na[m] sepius sequ[en]te h $\mathrm{n}$ [on] fit colisio ut posthabita coluisse samo hic illi[us] arma' ('Candenti is a better reading since usually when ' $h$ ' comes after there is no elision, as in posthabita coluisse samo hic illius arma [Aeneid I.16]'). At I.11.2 $\left(19^{v}\right)$ 'Leucothoe' in the text is corrected to 'Leuconoe', with an explanation from the Greek etymology. At III.24.4 $\left(103^{\mathrm{r}}\right)$, where the printed text gives 'Tyrrhenum omne tuis: \& mare ponticum', 'ponticum' is corrected to 'punicum', on the grounds that the Punic (Libyan) Sea is closer to the Tyrrhenian Sea than the Black Sea is. (Lambin later found in some manuscripts the reading 'mare Apullicum', and Cruquius's Blandinius vetustissimus had the reading 'mare publicum'. Some

\footnotetext{
46 Based on a comparison of Shackleton-Bailey's 1985 and Borzsàk's 1984 Teubner editions, and the Oxford text that is the basis for Rudd's 2004 Loeb. 'nominatis' (III.14.11) is obelized by Borzsàk and Shackleton-Bailey has '[i] nominatis'. Both Borzsàk and Rudd read 'pater' at IV.7.15 where the other texts have 'pius'.

47 But the following are some examples of less successful readings: 'metuende': 'at memorande' (I.12.23, 22 $)$; 'ictus': 'estus' (II.15.10, 69 ${ }^{\mathrm{r}}$ ); 'innixus': 'invisus' where modern texts read 'enisus'

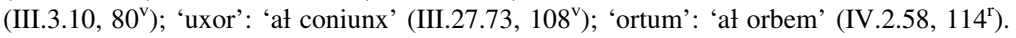


modern editions, following Lachmann, dispose of the geographical problem completely by reading the line as 'terrenum omne tuis et mare publicum.' $)^{48}$ Clearly these are not the conjectures of a great textual scholar, but they show that at least some discussion of textual problems was a part of Calphurnius's teaching.

Although the annotations to the text of the Odes show little interest in the moral dimension of the poems, the other marks used by Pirckheimer to highlight passages (manicules, marginal borders with ornate flourishes - but not underlining) do focus on sententiae for the commonplace book. Carefully drawn manicules point out the famous Horatian lines (e.g. 'dulce et decorum est', $79^{\text {r }}$; 'pallida mors aequo pulsat pede', $11^{\mathrm{r}}$ ), and ornate borders are frequently drawn along the left side of the text to highlight longer passages, sometimes with a brief comment (e.g. $79^{\mathrm{v}}$ : 'comendat silentium'). Pirckheimer does not generally note down parallel sententiae from other authors, but there is one example: at 'integra cum mente' (I.31.18-19), he writes 'sit mens sana in corpore sano' $\left(44^{\mathrm{v}}\right)$.

*

The annotations taken down by Pirckheimer during the courses on Horace he followed at Padua present an overall picture that is very much in line with what is known about broader trends in Quattrocento education. At the same time these annotations serve to affirm how stable and consistent were the methods of teaching the Latin classics across the centuries. The proximity of the comments made by Calphurnius and Regius in many cases to those found in Acro's commentary, and the use by Calphurnius of the manuscript paratexts, demonstrates the continued reliance of Renaissance humanist teachers on the medieval tradition. There are, though, also aspects that could be said to mark a distinctly Renaissance humanist approach: an increased interest in textual matters - both Calphurnius and Regius as part of their dictation gave textual readings that generally improved the text Pirckheimer had at his disposal; a closer attention to metrical analysis; and a more abundant, albeit fairly superficial, use of Greek. The other thing that marks these student notes distinctly as products of the Renaissance is their form: they are taken down in the margins of a printed book, a large format commentary edition. Many such annotated editions survive, and closer study of them, especially in cases where their uses can be located in particular institutional contexts, can tell us a great deal more about both continuities and changes in reading and writing practices in the era of print.

Acknowledgments This article was written during my term as a Research Associate at the John Rylands Research Institute; I am grateful also to the Renaissance Society of America for the award of a Paul Oskar Kristeller Memorial Grant to undertake part of this research.

Open Access This article is distributed under the terms of the Creative Commons Attribution 4.0 International License (http://creativecommons.org/licenses/by/4.0/), which permits unrestricted use, distribution, and reproduction in any medium, provided you give appropriate credit to the original author(s) and the source, provide a link to the Creative Commons license, and indicate if changes were made.

\footnotetext{
48 Exceptionally Rudd's 2004 Loeb, departing from the Oxford text, here reads 'Punicum' as had Calphurnius (elsewhere described as 'thinly attested').
} 